\title{
Runoff of Onega paleo-lake in late-glacial period: paleolimnological data
}

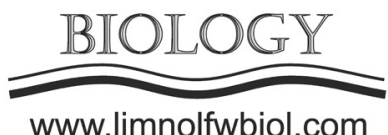

\author{
Orlov A.V. ${ }^{1,2 *}$, Subetto D.A. ${ }^{1,2}$, Potakhin M.S. ${ }^{2}$, Beliaev P.Yu. ${ }^{2,3}$ \\ ${ }^{1}$ Herzen State Pedagogical University of Russia, Nab. Moyki 48, St. Petersburg, 191186, Russia \\ ${ }^{2}$ Northern Water Problems Institute, Karelian Research Centre of the RAS, Aleksander Nevsky st. 50, Petrozavodsk, 185030, Republic \\ of Karelia, Russia \\ ${ }^{3}$ A.P. Karpinsky VSEGEI, Sredniy Prospekt V.O 74, St. Peterburg, 199106, Russia
}

\begin{abstract}
Bottom sediments of the small relict lakes Regozero, Chernoe, Anashkino, Rzhanoe and other bear important information about a history of Lake Paleo-Onega in the LGM-Holocene transition. We studied the core $4 \mathrm{~m}$ from bottom sediments of Lake Rzhanoe. The aim of the study was to test the hypothesis that there was an outflow canal from Lake Paleo-Onega in the LGM-Holocene transition.
\end{abstract}

Keywords: paleolimnoligy, lithology, lake-bottom sediments, glacial reservoir, Late Glacial period, Holocene, Onega lake

\section{Introduction}

The Onega lake basin in the Late Glacial time was under the influence of degrading cover glacier, so it experienced catastrophic changes. In the period of about 14000 - 13500 BP the Paleo Onega lake reached the maximum size and then degraded because of transgressions caused by opening several runoff channels in the period of $13200-12300$ BP. One of these channels was located to the North of the modern Shokshinskaya ridge. This narrow runoff channel existed for a short time and disappeared when the Paleo Onega lake level dropped. Nowadays, several small lakes (Regozero, Chernoe, Anashkino, Rzhanoe, etc.) are located in place of that paleochannel by which the channel can be traced.

\section{Material and methods}

Fieldwork was carried out in March 2020. It included investigation of bathymetric parameters and the bottom sediments coring of Lake Rzhanoe. Sampling was conducted from the ice cover (which was thick enough) using the Russian peat corer with sampling chamber $5 \mathrm{~cm}$ in diameter and $1 \mathrm{~m}$ long. The bottom sediment coring was conducted in 6 points in different parts of the lake for revealing the ancient alluvial deposits under the sediments of the modern lake.

\section{Results}

In a course of a field work a paleolimnoligical information was received that help researchers reconstruct the history of Lake Rzhanoe. A column of bottom sediments with a capacity of more than $4 \mathrm{~m}$ was selected. Alluvial deposits (coarse-grained sand with gravel) were found in the bottom part of the column.

\section{Discussions and conclusions}

Lake Rzhanoe is placed in area where in the Late Glacial time a narrow channel formed by mass of water flowed out from the Paleo Onega lake. This runoff channel existed for some time and disappeared due to the fall of the Paleo Onega lake level. In this time span, several isolated lakes were formed in deeper parts of the channel, so alluvial sediments were covered by small lakes in which the sedimentary processes started. For this reason coring the sediments of lakes, located in a place of the ancient channel, can provide researchers with the valuable information about the history of Paleo Onega lake formation and its level changes. The further researches will provide us with more information and accumulate the foundation for creating a reconstruction of the Onega lake development at various stages.

\section{Acknowledgments}

Research and fieldworks are supported by Russian Science Foundation (project 18-17-00176).

\section{References}

Pothakin M.S., Ryazancev P.A., Gybrich V.A. et al. 2017. Study of lake deposits of the South-Western Prionezhye region. In: Geoecological problems and sustainable development of the Baltic region Conference, pp 55-61. 